\title{
EVALUASI PENERAPAN AKUNTANSI PAJAK AIR PERMUKAAN PADA PERUSAHAAN DAERAH AIR MINUM KABUPATEN MINAHASA UTARA
}

\author{
Stephanie Selina Sheren Wowor ${ }^{1}$, Inggriani Elim² ${ }^{2}$, Sonny Pangerapan ${ }^{3}$ \\ ${ }^{1}$ Jurusan Akuntansi, Fakultas Ekonomi dan Bisnis, Universitas Sam Ratulangi, Jl. Kampus Unsrat, Kota \\ Manado, 95115, Indonesia \\ ${ }^{2}$ Jurusan Akuntansi, Fakultas Ekonomi dan Bisnis, Universitas Sam Ratulangi, Jl. Kampus Unsrat, Kota \\ Manado, 95115, Indonesia \\ ${ }^{3}$ Jurusan Akuntansi, Fakultas Ekonomi dan Bisnis, Universitas Sam Ratulangi, Jl. Kampus Unsrat, Kota \\ Manado, 95115, Indonesia \\ E-mail : sheren.wowor@yahoo.co.id
}

\begin{abstract}
Surface water tax is one of the local taxes levied by the provincial government as one of the sources of local revenue. Surface water taxes are a tax on the collection and/or utilization of surface water. The objective of this research is to know the use of surface water tax accounting whether the use of surface water tax has been in accordance with applicable laws, tax laws and local regulations. The research was conducted at the Regional Water Supply Company (PDAM) of North Minahasa Regency which is located at Worang By Pass Street Number 1, District Airmadidi. The method used in this research is comparative descriptive method. The results show that the PDAM of North Minahasa Regency calculated and paid a relatively small surface water tax for 2014, 2015 and 2016.
\end{abstract}

Keywords : tax, surface water, evaluation

\section{PENDAHULUAN}

Demi kelangsungan sistem dan pembangunan negara, pemerintah membutuhkan penerimaan rutin. Penerimaan negara berasal dari penerimaan perpajakan, penerimaan negara bukan pajak, dan penerimaan hibah dari dalam atau luar negeri. Pembangunan nasional yang mempunyai biaya yang tidak sedikitpun, tidak terlepas dari peran pajak sebagai sumber terbesar penerimaan kas negara. Oleh karena itu pemerintah terus berusaha menaikkan target penerimaan pajak dari tahun ke tahun, hal ini dimaksudkan agar program-program pemerintah dalam menjalankan roda pemerintahan untuk meningkatkan kesejahteraan masyarakat dapat ditingkatkan juga. Begitu juga untuk setiap daerah di Indonesia, demi menunjang sasaran pemerintah untuk pembangunan nasional, pemerintah daerah memiliki sumber pendapatan daerah yang terdiri dari Pendapatan Asli Daerah (PAD), dana perimbangan, dan lain-lain pendapatan daerah yang sah.

Berdasarkan Undang-Undang Nomor 33 Tahun 2004 Tentang Perimbangan Keuangan Antara Pusat dan Daerah menjelaskan bahwa Pendapatan Asli Daerah, selanjutnya disebut PAD adalah pendapatan yang diperoleh daerah yang dipungut berdasarkan peraturan daerah sesuai dengan peraturan perundang-undangan. Dalam Undang-Undang Republik Indonesia Nomor 28 Tahun 2009 Pasal 1 Ayat 10, dijelaskan bahwa pajak daerah adalah kontribusi wajib kepada daerah yang terutang oleh orang pribadi atau badan yang bersifat memaksa berdasarkan undang-undang, dengan tidak mendapatkan imbalan secara langsung dan digunakan untuk keperluan daerah bagi sebesar-besarnya kemakmuran rakyat. Sebagai salah satu sumber penerimaan, pajak daerah dan retribusi daerah ditetapkan dengan undang-undang yang pelaksanaannya di daerah diatur lebih lanjut dengan Peraturan Daerah (Perda).

Air merupakan sumber daya alam yang penting untuk kehidupan sehari-hari, jika tidak dipantau atau dibatasi pemakaiannya, serta tidak dikelola dengan baik akan menyebabkan 
menipisnya cadangan air di bumi. Air merupakan barang milik bersama, jika pemakai air tersebut hanya mementingkan kepentingan pribadi dan tidak mau bekerja sama dan saling menjaga antar pemakai air, misalnya dengan menghemat pemakaian air, maka pemakaian air yang tidak terkendali dapat menyebabkan persediaan air yang semakin menipis, dan akhirnya berimbas pada kurangnya bahkan habisnya kebutuhan utama manusia tersebut. Sebagai upaya mengendalikan pemakaian air, pemerintah mengenakan pajak kepada orang pribadi atau badan yang mengambil, memanfaatkan air permukaan dan air bawah tanah.

Pajak air permukaan telah beberapa kali mengalami perubahan, semula merupakan satu jenis pajak yang masuk dalam pajak daerah yang dipungut oleh pemerintah kabupaten/kota, bernama Pajak Pemanfaatan Air Bawah Tanah dan Air Permukaan. Berdasarkan UndangUndang Republik Indonesia Nomor 18 Tahun 1997 tentang Pajak Daerah dan Retribusi Daerah dengan tarif paling tinggi sebesar 20\% (dua puluh persen), yang kemudian mengalami perubahan dengan ditetapkannya Undang-Undang Republik Indonesia Nomor 34 Tahun 2000 tentang Perubahan Atas Undang-Undang Republik Indonesia Nomor 18 Tahun 1997 tentang Pajak Daerah dan Retribusi Daerah, dimana pajak tersebut berganti nama menjadi Pajak Pengambilan dan Pemanfaatan Air Bawah Tanah dan Air Permukaan (PPPABTAP) dan menjadi pajak yang dipungut oleh pemerintah tingkat I yaitu pemerintah provinsi. Hingga pada tanggal 15 bulan September tahun 2009, pemerintahan Presiden Susilo Bambang Yudhoyono menetapkan Undang-Undang Republik Indonesia Nomor 28 Tahun 2009 tentang Pajak Daerah dan Retribusi Daerah, dimana Pajak Pengambilan dan Pemanfaatan Air Bawah Tanah dan Air Permukaan (PPPABTAP) dipecah menjadi dua jenis pajak, yaitu Pajak Air Permukaan dan Pajak Air Tanah. Pajak Air Permukaan ditetapkan sebagai pajak provinsi, sedangkan Pajak Air Tanah ditetapkan menjadi pajak kabupaten/kota.

Pajak air permukaan merupakan salah satu sektor penerimaan pajak daerah untuk provinsi, Mardiasmo (2016: 13). Sesuai dengan Undang-Undang Nomor 28 Tahun 2009 tentang Pajak Daerah dan Retribusi Daerah, dijelaskan bahwa pajak air permukaan adalah pajak atas pengambilan dan/atau pemanfaatan air permukaan. Air permukaan adalah semua air yang terdapat pada permukaan tanah, tidak termasuk air laut, baik yang berada di laut maupun di darat. Peraturan yang mengatur tentang pajak daerah di Provinsi Sulawesi Utara yaitu Peraturan Daerah Provinsi Sulawesi Utara Nomor 7 Tahun 2011 tentang Pajak Daerah, dan peraturan yang mengatur tentang pajak air permukaan di Provinsi Sulawesi Utara yaitu Peraturan Gubernur Sulawesi Utara Nomor 42 Tahun 2014 tentang Tata Cara Perhitungan Harga Dasar Air Sebagai Dasar Penentuan Nilai Perolehan Air Untuk Penetapan Pajak Air Permukaan.

Seiring dengan ditetapkannya undang-undang dan peraturan perpajakan yang sering kali mengalami penambahan atau perubahan dari tahun ke tahun, mengakibatkan penyesuaian dalam transaksi perpajakan untuk laporan keuangan sebuah perusahaan. Untuk itu diperlukan adanya evaluasi baik dari dalam maupun dari luar perusahaan yang dilakukan untuk menilai apakah penerapan akuntansi untuk transaksi perpajakan khususnya pajak air permukaan telah sesuai dengan aturan-aturan yang berlaku saat ini. Oleh karena itu, penulis melakukan penelitian dengan judul "Evaluasi Penerapan Akuntansi Pajak Air Permukaan Pada Perusahaan Daerah Air Minum Kabupaten Minahasa Utara". 


\section{TINJAUAN PUSTAKA}

\subsection{Konsep Akuntansi}

Akuntansi adalah suatu disiplin ilmu yang terus berkembang sejalan dengan makin meningkatnya kebutuhan informasi keuangan. Perkembangan tersebut telah menempatkan akuntansi menjadi bagian yang tidak terpisahkan dari roda pemerintahan dan dunia usaha.

Pura (2013: 4), menyatakan bahwa akuntansi adalah seperangkat pengetahuan yang mempelajari perekayasaan dalam penyediaan jasa, yang berupa informasi keuangan kuantitatif dari suatu unit organisasi dan cara penyampaian (pelaporan) informasi tersebut kepada pihak yang berkepentingan untuk dijadikan dasar pengambilan keputusan ekonomi.

Informasi akuntansi pada dasarnya menyajikan informasi ekonomi kepada pihak yang memerlukan. Adapun pihak yang memerlukan informasi akuntansi terbagi ke dalam 2 (dua) jenis yaitu pihak eksternal dan pihak internal. Pihak eksternal terdiri dari pemegang saham, pemerintah, dan masyarakat sedangkan pihak internal terdiri dari pihak manajemen perusahaan yang bersangkutan dan karyawan.

\subsection{Konsep Pajak}

Pajak memiliki berbagai definisi yang pada hakekatnya mempunyai pengertian yang sama. Berdasarkan Undang-Undang Nomor 6 Tahun 1983 yang telah diubah dalam UndangUndang Nomor 28 Tahun 2007 tentang Ketentuan Umum dan Tata Cara Perpajakan, Pajak adalah kontribusi wajib kepada negara yang terutang oleh orang pribadi atau badan yang bersifat memaksa berdasarkan undang-undang, dengan tidak mendapatkan imbalan secara langsung dan digunakan untuk keperluan negara bagi sebesar-besarnya kemakmuran rakyat.

Menurut Waluyo (2013: 2), Pajak adalah iuran kepada negara (yang dapat dipaksakan) yang terutang oleh yang wajib membayarnya menurut peraturan-peraturan, dengan tidak mendapat prestasi kembali, yang langsung dapat ditunjuk, dan yang gunanya adalah untuk membiayai pengeluaran-pengeluaran umum berhubung dengan tugas negara yang menyelenggarakan pemerintahan.

\subsection{Pajak Daerah}

Menurut Undang-Undang Nomor 28 Tahun 2009 Tentang Pajak Daerah dan Retribusi Daerah, Pajak Daerah adalah kontribusi wajib kepada daerah yang terutang oleh orang pribadi atau badan yang bersifat memaksa berdasarkan undang-undang, dengan tidak mendapatkan imbalan secara langsung dan digunakan untuk keperluan daerah bagi sebesarbesarnya keperluan rakyat.

Pajak daerah adalah iuran wajib yang dilakukan oleh orang pribadi atau badan kepada daerah tanpa imbalan langsung yang seimbang, yang dapat dipaksakan berdasarkan peraturan perundang-undangan yang berlaku. (Siahaan 2013: 9).

\subsection{Pajak Air Permukaan}

\section{Pengertian Pajak Air Permukaan}

Pajak Air Permukaan adalah pajak atas pengambilan dan/atau pemanfaatan air permukaan. Air permukaan yang dimaksud adalah semua air yang terdapat pada permukaan tanah, tidak termasuk air laut, baik yang ada di laut maupun di darat. Pajak air permukaan termasuk dalam pajak daerah yang dipungut oleh Pemerintah Tingkat I atau Pemerintah Provinsi.

\section{Dasar Hukum Pemungutan Pajak Air Permukaan}

Dasar hukum pemungutan pajak air permukaan di Provinsi Sulawesi Utara adalah sebagai berikut:

a. Undang-Undang Nomor 28 Tahun 2009 tentang Pajak Daerah dan Retribusi Daerah.

b. Undang-Undang Nomor 34 Tahun 2000 tentang Perubahan atas Undang-Undang Nomor 18 Tahun 1997 tentang Pajak Daerah dan Retribusi Daerah.

c. Peraturan Pemerintah Nomor 65 Tahun 2001 tentang Pajak Daerah. 
d. Peraturan Pemerintah Nomor 91 Tahun 2010 tentang Jenis Pajak Yang Dipungut Berdasarkan Penetapan Kepala Daerah atau Dibayar Sendiri Oleh Wajib Pajak.

e. Peraturan Menteri Dalam Negeri Nomor 170 Tahun 1997 tentang Pedoman Tata Cara Pemungutan Pajak Daerah.

f. Peraturan Daerah Provinsi Sulawesi Utara Nomor 7 Tahun 2011 tentang Pajak Daerah.

g. Peraturan Gubernur Sulawesi Utara Nomor 42 Tahun 2014 tentang Tata Cara Perhitungan Harga Dasar Air Sebagai Dasar Penentuan Nilai Perolehan Air Untuk Penetapan Pajak Air Permukaan.

\section{Dasar Pengenaan, Tarif, dan Cara Perhitungan Pajak Air Permukaan}

a. Dasar Pengenaan Pajak Air Permukaan

Dasar pengenaan pajak air permukaan adalah Nilai Perolehan Air Permukaan (NPAP). NPAP dinyatakan dalam rupiah yang dihitung dengan mempertimbangkan sebagian atau seluruh faktor-faktor berikut:

1. Jenis sumber air;

2. Lokasi sumber air;

3. Tujuan pengambilan dan/atau pemanfaatan air;

4. Volume air yang diambil dan/atau dimanfaatkan;

5. Kualitas air;

6. Luas areal tempat pengambilan dan/atau pemanfaatan air;

7. Tingkat kerusakan lingkungan yang diakibatkan oleh pengambilan dan/atau pemanfaatan air.

NPAP diperoleh dari perkalian antara volume air per bulan dengan Harga Dasar Air. Cara menghitung harga dasar air permukaan adalah mengalikan Faktor Nilai Air dengan Harga Air Baku. Sesuai dengan Peraturan Gubernur Sulawesi Utara Nomor 42 Tahun 2014, Perhitungan Harga Dasar Air sebagai dasar penentuan nilai perolehan air dapat dilihat pada tabel di bawah ini.

Tabel 2.1 Penentuan Nilai Perolehan Air

\begin{tabular}{|c|c|c|c|c|}
\hline \multirow[t]{3}{*}{ No. } & \multirow{3}{*}{$\begin{array}{c}\text { Kelompok Jenis } \\
\text { Pengambilan/Pemanfaatan Air }\end{array}$} & \multicolumn{3}{|c|}{ Nilai Perolehan Air } \\
\hline & & \multirow{2}{*}{$\begin{array}{l}\text { Volum } \\
\text { e *) }\end{array}$} & \multicolumn{2}{|c|}{ Harga Dasar Air } \\
\hline & & & $\begin{array}{c}\text { Faktor Nilai } \\
\text { Air }\end{array}$ & $\begin{array}{l}\text { Harga Air } \\
\text { Baku / M3 }\end{array}$ \\
\hline 1 & $\begin{array}{l}\text { Perusahaan Daerah Air Minum } \\
\text { (PDAM) }\end{array}$ & $*$ & 1 & Rp 300 \\
\hline 2 & $\begin{array}{l}\text { Industri atau Perusahaan dengan Bahan } \\
\text { Baku Air }\end{array}$ & $*$ & 1,2 & Rp 300 \\
\hline 3 & Pertambangan & $*$ & 1,1 & Rp 300 \\
\hline 4 & $\begin{array}{l}\text { Sarana Rekreasi atau Pengisian } \\
\text { Pemandian }\end{array}$ & $*$ & 1,3 & Rp 300 \\
\hline 5 & Perusahaan Listrik Negara (PLN) & * & 1 & Rp 50/KWH \\
\hline
\end{tabular}

*) Volume yang dilaporkan oleh wajib pajak.

(sumber: Peraturan Gubernur Sulawesi Utara Nomor 42 Tahun 2014)

b. Tarif Pajak Air Permukaan

Sesuai dengan Undang-Undang Nomor 28 Tahun 2009 Pasal 24, tarif pajak air permukaan ditetapkan paling tinggi sebesar $10 \%$ (sepuluh persen). Selanjutnya ditetapkan 
dengan Peraturan Daerah dimana dalam Peraturan Gubernur Nomor 42 Tahun 2014 Pasal 4 Ayat (5) tarif pajak air permukaan adalah sebesar $10 \%$ (sepuluh persen) dari nilai perolehan air.

c. Cara Perhitungan Pajak Air Permukaan

Besaran pokok pajak air permukaan yang terutang dihitung dengan cara mengalikan tarif dengan dasar pengenaan pajak. Secara umum perhitungan pajak air permukaan adalah sesuai dengan rumus berikut:

$$
\begin{aligned}
& \text { Pajak Terutang }=\text { Tarif Pajak } x \text { Dasar Pengenaan Pajak } \\
& =\text { Tarif Pajak } x \text { Nilai Perolehan Air Permukaan }
\end{aligned}
$$

\section{METODE PENELITIAN}

\subsection{Jenis Penelitian}

Penelitian ini akan membahas tentang penerapan akuntansi atas pajak air permukaan pada Perusahaan Daerah Air Minum Kabupaten Minahasa Utara. Metode yang digunakan dalam penelitian ini adalah metode deskriptif.

Penelitian ini termasuk dalam jenis penelitian komparatif yaitu membandingkan penerapan akuntansi Pajak Air Permukaan yang dilakukan perusahaan dengan undangundang tentang perpajakan pada umumnya dan pajak air permukaan pada khususnya.

\subsection{Metode Pengumpulan Data} Jenis Data

Menurut Sugiyono (2012: 7), data merupakan sekumpulan informasi yang diperlukan untuk mengambil keputusan. Jenis data yang digunakan penulis yaitu jenis data kuantitatif dimana data disajikan dalam bentuk angka.

\section{Sumber Data}

Sumber data yang digunakan dalam penelitian ini adalah data primer dan data sekunder. Data primer yang diambil penulis dari perusahaan yaitu data mengenai jenis sumber air dan pemakaiannya, data perhitungan pajak air permukaan yang dilakukan PDAM, serta data mengenai pencatatan, pembayaran dan pelaporan pajak air permukaan oleh PDAM. Sedangkan data sekunder diperoleh melalui studi dokumentasi dengan mempelajari berbagai tulisan dalam buku, internet, jurnal dan skripsi yang berhubungan dengan penelitian.

\subsection{Metode Analisis}

Menurut Sugiyono (2012: 2), metode penelitian pada dasarnya merupakan cara ilmiah untuk mendapatkan data dengan tujuan dan kegunaan tertentu. Metode analisis yang digunakan peneliti adalah metode deskriptif. Menurut Sugiyono (2012: 29), metode deskriptif adalah metode yang digunakan untuk menggambar atau menganalisis, membandingkan suatu hasil penelitian tetapi tidak digunakan untuk membuat kesimpulan yang lebih luas. Dalam tahap ini peneliti menganalisis data dengan langkah-langkah sebagai berikut:

a. Peneliti mengumpulkan data tentang volume penggunaan air permukaan di PDAM Kabupaten Minahasa Utara selama tahun 2014, 2015 dan 2016 dan data tentang volume air produksi, volume air distribusi dan volume air terjual di PDAM Kabupaten Minahasa Utara selama tahun 2014, 2015 dan 2016.

b. Menganalisis dasar pengenaan pajak air permukaan dan dasar perhitungan pajak air permukaan yang dilakukan perusahaan.

c. Mengevaluasi pencatatan, pembayaran dan pelaporan pajak air permukaan di Perusahaan Daerah Air Minum Kabupaten Minahasa Utara. 


\section{HASIL PENELITIAN DAN PEMBAHASAN}

\subsection{Hasil Penelitian}

\section{Dasar Pengenaan Pajak Air Permukaan}

Berdasarkan data yang diberikan pihak PDAM dan wawancara yang dilakukan dengan pihak manajemen PDAM Kabupaten Minahasa Utara, jumlah pajak air permukaan dihitung dengan cara mengalikan tarif pajak air permukaan yang berlaku saat ini yaitu sebesar $10 \%$ (sepuluh persen) dengan dasar pengenaan pajak.

Dasar pengenaan pajak adalah nilai perolehan air permukaan, yang dihitung dengan cara mengalikan volume air yang digunakan dalam satuan meter kubik $\left(\mathrm{m}^{3}\right)$ dengan harga dasar air. Harga dasar air dihitung dengan cara mengalikan faktor nilai air, yang dalam hal ini PDAM mempunyai bobot 1, dengan harga air baku per $\mathrm{m}^{3}$, yang dalam hal ini Rp. 300 .

\section{Dasar Perhitungan Pajak Air Permukaan PDAM Kabupaten Minahasa Utara}

Data yang dievaluasi dalam penelitian ini adalah data tahun 2014, 2015, dan 2016. Sesuai dengan laporan yang diberikan pihak manajemen, PDAM Kabupaten Minahasa Utara melaporkan data tentang penggunaan air permukaan untuk tahun 2014, 2015, dan 2016 yang dapat dilihat pada tabel di bawah ini:

\section{Tabel 4.1 Laporan Penggunaan Air Permukaan PDAM Kabupaten Minahasa Utara Volume Penggunaan Air Permukaan $\left(\mathrm{m}^{3}\right)$}

\begin{tabular}{|c|c|c|c|c|}
\hline \multirow[b]{2}{*}{ No. } & \multirow[b]{2}{*}{ Bulan } & \\
\hline & & Tahun 2016 & Tahun 2015 & Tahun 2014 \\
\hline 1. & Januari & 4.662 & 18.891 & 21.576 \\
\hline 2. & Februari & 4.843 & 19.873 & 21.487 \\
\hline 3. & Maret & 5.064 & 19.673 & 21.752 \\
\hline 4. & April & 5.065 & 18.223 & 23.724 \\
\hline 5. & Mei & 5.069 & 15.644 & 22.197 \\
\hline 6. & Juni & 4.896 & 19.260 & 21.442 \\
\hline 7. & Juli & 4.594 & 15.835 & 21.159 \\
\hline 8. & Agustus & 4.341 & 16.044 & 20.601 \\
\hline 9. & September & 4.553 & 17.430 & 22.977 \\
\hline 10. & Oktober & 4.807 & 15.601 & 22.355 \\
\hline 11. & November & 4.343 & 17.237 & 21.341 \\
\hline 12. & Desember & 4.632 & 15.403 & 20.507 \\
\hline & Jumlah & 56.869 & 209.114 & 261.118 \\
\hline
\end{tabular}

(sumber: PDAM Kab. MINUT, 2016)

Berdasarkan laporan penggunaan air permukaan tersebut, PDAM Kabupaten Minahasa Utara menghitung sendiri jumlah pajak air permukaan yang tertanggung sebagai berikut :

Tahun 2014

Tarif pajak air permukaan $\quad=10 \%$

Volume penggunaan air $\quad=261.118 \mathrm{~m}^{3} \quad$ (jumlah setahun)

Faktor nilai air $\quad=1$

Harga air baku $\quad=$ Rp 300

Perhitungan jumlah pajak tertanggung sebagai berikut :

$10 \%$ × $(261.118 \times 1 \quad$ × $\quad \operatorname{Rp~300)~}=\mathbf{R p ~ 7 . 8 3 3 . 5 4 0}$

Tahun 2015

Tarif pajak air permukaan $=10 \%$ 


\begin{tabular}{|c|c|}
\hline Volume penggunaan air & $=209.114 \mathrm{~m}^{3} \quad$ (jumlah setahun) \\
\hline Faktor nilai air & $=1$ \\
\hline Harga air baku & $=\operatorname{Rp} 300$ \\
\hline Perhitungan jumlah pajak te & tanggung sebagai berikut: \\
\hline $\begin{array}{l}10 \% \times(209.114 \times 1 \\
\text { Tahun } 2016\end{array}$ & $\operatorname{Rp} 300)=\operatorname{Rp} 6.273 .420$ \\
\hline Tarif pajak air permukaan & $=10 \%$ \\
\hline Volume penggunaan air & (jumlah setahun) \\
\hline Faktor nilai air & $=1$ \\
\hline Harga air baku & $=\operatorname{Rp} 300$ \\
\hline Perhitungan jumlah pajak te & anggung sebag \\
\hline $10 \% \quad x \quad(56.869 \times 1 \times$ & $\operatorname{Rp} 300)$ \\
\hline
\end{tabular}

\subsection{Pembahasan}

\section{Penerapan Akuntansi Pajak Air Permukaan Pada Perusahaan Daerah Air Minum (PDAM) Kabupaten Minahasa Utara}

PDAM Kabupaten Minahasa Utara menyerahkan data laporan penggunaan air permukaan kepada Dinas Pendapatan Daerah atau yang sekarang telah berubah nama menjadi Badan Pengelola Pajak dan Retribusi Daerah Provinsi. Berdasarkan laporan tersebut, Dinas Pendapatan Daerah atau Badan Pengelola Pajak dan Retribusi Daerah Provinsi mengeluarkan rekapitulasi penetapan penggunaan air permukaan beserta Surat Ketetapan Pajak Daerah (SKPD) atau dokumen lain yang dipersamakan.

Atas rekapitulasi dan SKPD tersebut, PDAM Kabupaten Minahasa Utara yang dalam hal ini bagian pembukuan, menerbitkan voucher sesuai dengan jumlah yang ditetapkan, dan menjurnal transaksi tersebut ke dalam Daftar Voucher Utang Yang Harus Dibayar (DVHD). Setelah bagian pembukuan menerbitkan voucher dan menjurnal transaksi tersebut ke dalam DVHD, voucher tersebut diberikan kepada bagian keuangan untuk dibayarkan. Setelah bagian keuangan membayar dan menandatangani voucher yang telah dibayarkan, voucher tersebut dikembalikan kepada bagian pembukuan untuk dicatat dalam Jurnal Bayar Kas/Bank (JBK).

Perusahaan Daerah Air Minum (PDAM) Kabupaten Minahasa Utara menghitung sendiri pajak air permukaan yang tertanggung, dengan menggunakan tarif yang sesuai dengan Undang-Undang Nomor 28 Tahun 2009, yaitu $10 \%$ (sepuluh persen).

Untuk nilai perolehan air yang terapkan, khususnya volume air yang dilaporkan oleh PDAM Kabupaten Minahasa Utara, terdapat ketidaksesuaian dengan jumlah pemakaian volume air permukaan, yang seharusnya menggunakan debit volume air yang diambil dan/atau dimanfaatkan, dalam hal ini volume air yang terjual kepada pelanggan melalui semua jenis sumber air baku yang digunakan oleh PDAM Kabupaten Minahasa Utara. Namun pada kenyataannya, PDAM Kabupaten Minahasa Utara menggunakan angka volume air yang terjual melalui jenis sumber air baku yang hanya berasal dari beberapa daerah saja. Oleh karena itu, jumlah volume air yang dilaporkan untuk perhitungan pajak air permukaan tidak sama dengan jumlah volume air yang diambil dan/atau dimanfaatkan oleh PDAM, dalam hal ini volume air yang terjual kepada pelanggan melalui semua jenis sumber air baku yang digunakan PDAM.

Dalam data penggunaan air yang diberikan PDAM Kabupaten Minahasa Utara, selama tahun 2014, 2015 dan 2016 tercatat bahwa volume air hasil produksi, volume air distribusi dan volume air yang terjual melalui semua jenis sumber air baku yang digunakan PDAM Kabupaten Minahasa Utara dapat dilihat pada tabel di bawah ini: 


\begin{tabular}{|c|c|c|c|c|}
\hline \multicolumn{5}{|c|}{ Tabel 4.2 Volume Air Produksi PDAM Kabupaten Minahasa Utara } \\
\hline \multirow{2}{*}{ No. } & \multirow{2}{*}{ Bulan } & \multicolumn{3}{|c|}{ Volume Air Produksi $\left(\mathrm{m}^{3}\right)$} \\
\hline & & Tahun 2016 & Tahun 2015 & Tahun 2014 \\
\hline 1. & Januari & 219.024 & 232.740 & 298.080 \\
\hline 2. & Februari & 219.888 & 232.740 & 298.080 \\
\hline 3. & Maret & 219.888 & 232.740 & 298.080 \\
\hline 4. & April & 219.888 & 232.740 & 301.860 \\
\hline 5. & Mei & 219.888 & 232.740 & 301.860 \\
\hline 6. & Juni & 219.888 & 232.740 & 232.740 \\
\hline 7. & Juli & 219.888 & 232.740 & 232.740 \\
\hline 8. & Agustus & 219.888 & 232.740 & 232.740 \\
\hline & September & 219.888 & 232.740 & 232.740 \\
\hline 10. & Oktober & 219.888 & 206.064 & 232.740 \\
\hline 11. & November & 219.888 & 206.064 & 232.740 \\
\hline 12. & Desember & 219.888 & 206.064 & 232.740 \\
\hline & Jumlah & 2.637 .792 & 2.712.852 & 3.127 .140 \\
\hline
\end{tabular}

(sumber: PDAM Kab. MINUT, 2016)

Tabel 4.3 Volume Air Distribusi PDAM Kabupaten Minahasa Utara

\begin{tabular}{|c|c|c|c|c|}
\hline \multirow{2}{*}{ No. } & \multirow{2}{*}{ Bulan } & \multicolumn{3}{|c|}{ Volume Air Distribusi $\left(\mathbf{m}^{3}\right)$} \\
\hline & & Tahun 2016 & Tahun 2015 & Tahun 2014 \\
\hline 1. & Januari & 219.024 & 232.740 & 298.080 \\
\hline 2. & Februari & 219.888 & 232.740 & 298.080 \\
\hline 3. & Maret & 219.888 & 232.740 & 298.080 \\
\hline 4. & April & 219.888 & 232.740 & 301.860 \\
\hline 5. & Mei & 219.888 & 232.740 & 301.860 \\
\hline 6. & Juni & 219.888 & 232.740 & 232.740 \\
\hline 7. & Juli & 219.888 & 232.740 & 232.740 \\
\hline 8. & Agustus & 219.888 & 232.740 & 232.740 \\
\hline 9. & September & 219.888 & 232.740 & 232.740 \\
\hline 10. & Oktober & 219.888 & 206.064 & 232.740 \\
\hline 11. & November & 219.888 & 206.064 & 232.740 \\
\hline 12. & Desember & 219.888 & 206.064 & 232.740 \\
\hline & Jumlah & 2.637 .792 & 2.712.852 & 3.127 .140 \\
\hline
\end{tabular}

(sumber: PDAM Kab. MINUT, 2016) 


\begin{tabular}{|c|c|c|c|c|}
\hline \multicolumn{5}{|c|}{ Tabel 4.4 Volume Air Terjual PDAM Kabupaten Minahasa Utara } \\
\hline \multirow{2}{*}{ No. } & \multirow{2}{*}{ Bulan } & \multicolumn{3}{|c|}{ Volume Air Terjual $\left(\mathrm{m}^{3}\right)$} \\
\hline & & Tahun 2016 & Tahun 2015 & Tahun 2014 \\
\hline 1. & Januari & 75.089 & 94.874 & 96.883 \\
\hline 2. & Februari & 76.545 & 89.563 & 94.407 \\
\hline 3. & Maret & 72.540 & 86.069 & 93.099 \\
\hline 4. & April & 75.619 & 92.617 & 94.835 \\
\hline 5. & Mei & 76.895 & 80.323 & 94.533 \\
\hline 6. & Juni & 74.747 & 90.693 & 91.754 \\
\hline 7. & Juli & 75.321 & 82.099 & 93.361 \\
\hline 8. & Agustus & 77.034 & 80.079 & 90.936 \\
\hline 9. & September & 72.575 & 83.514 & 94.217 \\
\hline 10. & Oktober & 74.488 & 77.145 & 97.121 \\
\hline & November & 71.693 & 80.710 & 94.836 \\
\hline 12. & Desember & 71.527 & 75.636 & 89.809 \\
\hline & Jumlah & 894.073 & 1.013 .322 & 1.125 .791 \\
\hline
\end{tabular}

(sumber: PDAM Kab. MINUT, 2016)

Berdasarkan data di atas, dapat dilihat bahwa jumlah volume air produksi dan volume air distribusi PDAM Kabupaten Minahasa Utara sama besar untuk tahun 2014, 2015 dan 2016, namun untuk volume air yang terjual tidak sama. Berdasarkan hasil penelitian, adanya kesalahan jumlah volume air yang dilaporkan oleh PDAM untuk perhitungan pajak air permukaan. Tahun 2014, volume air yang dilaporkan untuk perhitungan pajak air permukaan sebanyak $261.118 \mathrm{~m}^{3}$ dan volume air yang seharusnya dilaporkan untuk perhitungan pajak air permukaan sebanyak $1.125 .791 \mathrm{~m}^{3}$. Tahun 2015 , volume air yang dilaporkan sebanyak $209.114 \mathrm{~m}^{3}$ dan volume air yang seharusnya dilaporkan untuk perhitungan pajak air permukaan sebanyak $1.013 .322 \mathrm{~m}^{3}$. Tahun 2016, volume air yang dilaporkan sebanyak $56.869 \mathrm{~m}^{3}$ dan volume air yang seharusnya dilaporkan untuk perhitungan pajak air permukaan sebanyak $894.073 \mathrm{~m}^{3}$. Selisih volume air yang seharusnya dilaporkan untuk perhitungan pajak air permukaan dan volume air yang dilaporkan PDAM adalah sebagai berikut:

Tabel 4.5 Selisih Pelaporan Volume Air Permukaan PDAM Kabupaten Minahasa Utara

\section{$\begin{array}{llll}\text { Volume Air }\left(\mathrm{m}^{3}\right) & \text { Tahun } 2016 & \text { Tahun } 2015 & \text { Tahun } 2014\end{array}$}

\begin{tabular}{crrr}
\hline Air Permukaan & 894.073 & 1.013 .322 & 1.125 .791 \\
\hline Dilaporkan & 56.869 & 209.114 & 261.118 \\
\hline Selisih & 837.204 & 804.208 & 864.673 \\
\hline
\end{tabular}

(sumber: Data Olahan Sendiri)

Hasil penelitian menunjukkan perusahaan kurang melaporkan volume air yang seharusnya dijadikan dasar pengenaan pajak air permukaan. Perhitungan jumlah pajak air permukaan yang seharusnya terutang adalah sebagai berikut :

Tahun 2014

Tarif $\mathrm{x}$ (Volume air $\mathrm{x}$ Faktor nilai air $\mathrm{x}$ Harga air baku)

$10 \% \quad \mathrm{x}(1.125 .791 \quad \mathrm{x} \quad 1 \quad \mathrm{x} \quad \mathrm{Rp} 300) \quad=\mathbf{R p} 33.773 .730$

Tahun 2015 
Tarif $\mathrm{x}$ (Volume air $\mathrm{x}$ Faktor nilai air $\mathrm{x}$ Harga air baku)

$10 \% \quad \mathrm{x}(1.013 .322 \times 1 \quad 1 \quad \mathrm{x} \quad \operatorname{Rp} 300)=\mathbf{R p} 30.399 .660$

Tahun 2016

Tarif $\mathrm{x}$ (Volume air $\mathrm{x}$ Faktor nilai air $\mathrm{x}$ Harga air baku)

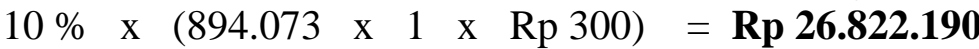

Pada tahun 2014, PDAM Kabupaten Minahasa Utara seharusnya membayar pajak air permukaan sebesar Rp. 33.773.730, namun yang dilaporkan dan dibayar PDAM hanya sebesar Rp. 7.833.540. Tahun 2015, perusahaan seharusnya membayar pajak air permukaan sebesar Rp.30.399.660, namun yang dilaporkan dan dibayar PDAM hanya sebesar Rp.6.273.420. Tahun 2016, perusahaan seharusnya membayar pajak air permukaan sebesar Rp. 26.822.190, namun yang dilaporkan dan dibayar PDAM hanya sebesar Rp. 1.706.070. Berdasarkan data diatas, perusahaan jadinya kurang membayar Pajak Air Permukaan (PAP) yang seharusnya terutang dapat dilihat dalam tabel di bawah ini:

Tabel 4.6 Selisih Perhitungan Pajak Air Permukaan PDAM Kabupaten Minahasa Utara

Pajak Air Permukaan (Rp) Tahun $2016 \quad$ Tahun $2015 \quad$ Tahun 2014

\begin{tabular}{crrr}
\hline Seharusnya dibayar & 26.822 .190 & 30.399 .660 & 33.773 .730 \\
\hline Yang dibayar & 1.706 .070 & 6.273 .420 & 7.833 .540 \\
\hline Selisih & 25.116 .120 & 24.126 .240 & 25.940 .190 \\
\hline
\end{tabular}

(sumber: Data Olahan Sendiri)

Dalam melakukan pembayaran pajak yang terutang, PDAM Kabupaten Minahasa Utara menggunakan Surat Ketetapan Pajak Daerah (SKPD) atau dokumen lain yang dipersamakan berdasarkan penetapan Kepala Daerah sesuai dengan Peraturan Pemerintah Republik Indonesia Nomor 91 Tahun 2010 tentang Jenis Pajak Daerah Yang Dipungut Berdasarkan Penetapan Kepala Daerah Atau Dibayar Sendiri Oleh Wajib Pajak. PDAM melakukan pembayaran (menyetor) langsung ke rekening penerimaan Pemerintah Provinsi Sulawesi Utara (Bank SulutGo) dan bukti setorannya dicopy lalu disampaikan ke Kantor Unit Pelaksana Teknis Dinas (UPTD) Airmadidi.

\section{KESIMPULAN DAN SARAN}

\subsection{Kesimpulan}

Berdasarkan hasil penelitian yang telah dilakukan, peneliti mengemukakan kesimpulan sebagai berikut:

1. PDAM Kabupaten Minahasa Utara menggunakan dasar pengenaan pajak air permukaan tidak sesuai dengan Undang-Undang Nomor 28 Tahun 2009 tentang Pajak Daerah dan Retribusi Daerah dan Peraturan Gubernur Sulawesi Utara Nomor 42 Tahun 2014 tentang Tata Cara Perhitungan Harga Dasar Air Sebagai Dasar Penentuan Nilai Perolehan Air Untuk Penetapan Pajak Air Permukaan, karena PDAM menggunakan angka volume air yang diproduksi, didistribusi, dan yang terjual melalui sumber air baku yang terdapat di beberapa tempat saja.

2. PDAM Kabupaten Minahasa Utara membayar pajak air permukaan relatif kecil untuk tahun 2014, 2015 dan 2016, karena dasar perhitungan yang digunakan PDAM tidak 
memasukkan seluruh volume air yang diambil dan /atau dimanfaatkan sehingga hasil perhitungan untuk pembayaran pajak air permukaan menjadi sedikit.

\subsection{Saran}

Adapun saran yang ingin disampaikan peneliti berdasarkan hasil penelitian yang dilakukan adalah sebagai berikut:

1. PDAM Kabupaten Minahasa Utara memasang meter induk untuk setiap sumber air baku yang ada, sehingga volume air produksi dan distribusi dapat dicatat dan dilaporkan dengan angka yang tepat. Dengan demikian, PDAM Kabupaten Minahasa Utara juga dapat mencatat volume air kehilangan dengan angka yang tepat sehingga dapat diminimalisir dan menambah pendapatan perusahaan.

2. Perhitungan pajak air permukaan PDAM Kabupaten Minahasa Utara menggunakan angka volume air yang tepat yaitu volume air produksi dibagi dengan volume air distribusi dikalikan dengan volume air terjual dari semua sumber air baku, sehingga perhitungan pajak air permukaan yang dilakukan PDAM Kabupaten Minahasa Utara sesuai dengan undang-undang dan peraturan perpajakan yang berlaku.

\section{DAFTAR PUSTAKA}

Halim, Badul. M. Kusufi, Syam. 2012. Akuntansi Sektor Publik: Akuntansi Keuangan Daerah. Edisi 4. Penerbit Salemba Empat. Jakarta.

Harrison Jr, Walter T. Horgren, Walter T. Thomas, C. William. Suwardy, Themin. 2013. Akuntansi Keuangan. Penerbit Erlangga. Jakarta.

Mardiasmo. 2016. Perpajakan. Edisi Revisi. Penerbit Andi. Yogyakarta.

Pemerintah Republik Indonesia. 2009. Undang-Undang Nomor 28 Tahun 2009 Tentang Pajak Daerah Dan Retribusi Daerah. Jakarta.

Pemerintah Republik Indonesia. 2000. Undang-Undang Nomor 34 Tahun 2000 Tentang Perubahan Atas Undang-Undang Nomor 18 Tahun 1997 Tentang Pajak Daerah Dan Retribusi Daerah. Jakarta.

Pemerintah Republik Indonesia. 2001. Peraturan Pemerintah Nomor 65 Tahun 2001 Tentang Pajak Daerah. Jakarta.

Pemerintah Republik Indonesia. 2010. Peraturan Pemerintah Nomor 91 Tahun 2010 Tentang Jenis Pajak Yang Dipungut Berdasarkan Penetapan Kepala Daerah Atau Dibayar Sendiri Oleh Wajib Pajak. Jakarta.

Peraturan Menteri Dalam Negeri Nomor 170 Tahun 1997 Tentang Pedoman Tata Cara Pemungutan Pajak Daerah. Jakarta.

Peraturan Daerah Provinsi Sulawesi Utara Nomor 7 Tahun 2011 Tentang Pajak Daerah. Manado.

Peraturan Gubernur Sulawesi Utara Nomor 42 Tahun 2014 Tentang Tata Cara Perhitungan Harga Dasar Air Sebagai Dasar Penentuan Nilai Perolehan Air Untuk Penetapan Pajak Air Permukaan. Manado.

Perusahaan Daerah Air Minum Kabupaten Minahasa Utara. 2016. Profil PDAM Kabupaten Minahasa Utara. Airmadidi.

Priyati, Novi. 2013. Pengantar Akuntansi. Penerbit Indeks. Jakarta.

Pura, Rahman. 2013. Pengantar Akuntansi I. Penerbit Erlangga. Jakarta.

Resmi, Siti. 2013. Perpajakan: Teori dan Kasus. Penerbit Salemba Empat. Jakarta.

Siahaan, Marihot Pahala. 2013. Pajak Daerah dan Retribusi Daerah. Edisi Revisi. Penerbit Rajawali Pers. Jakarta.

Sugiyono, 2012. "Metode Penelitian Kuantitatif, Kualitatif dan R\&D”. Alfabeta, CV. Bandung.

Waluyo. 2013. Perpajakan Indonesia. Penerbit Salemba Empat. Jakarta. 